\title{
Temperature modulates estrone degradation and biological effects of exposure in fathead minnows
}

\author{
M.K. Cox ${ }^{\text {a }}$, K.N. Peterson ${ }^{\text {b }}$, D. Tan ${ }^{\text {b }}$, P.J. Novak ${ }^{\text {, }}$, H.L. Schoenfuss ${ }^{\text {a,* }}$, J.L. Ward ${ }^{\text {a,1 }}$ \\ a Department of Biology, Saint Cloud State University, 720 Fourth Avenue South, Saint Cloud, MN 56301, United States \\ b Department of Civil, Environmental, and Geo- Engineering, University of Minnesota, 500 Pillsbury Drive S.E., Minneapolis, MN 55455, United States
}

\section{H I G H L I G H T S}

- Estrone and effluent temperature interact to affect fish with unknown consequences.

- Identified effects of temperature on E1 degradation in wastewater and exposed fish.

- Ran nitrification experiments and fish estrone exposures at multiple temperatures.

- Cooler temperatures slowled E1 degradation and produced sex-specific effects in fish.

- Seasonal variation modifies E1 degradation in wastewater and E1 exposure in fish.

\section{A R T I C L E I N F O}

\section{Article history:}

Received 18 July 2017

Received in revised form 20 September 2017

Accepted 8 October 2017

Available online 18 October 2017

Editor: D. Barcelo

\section{Keywords:}

Estrogens

Fathead minnows

Reproduction

Vitellogenin

Histology

Wastewater treatment

\section{G R A P H ICA L A B S T RACT}

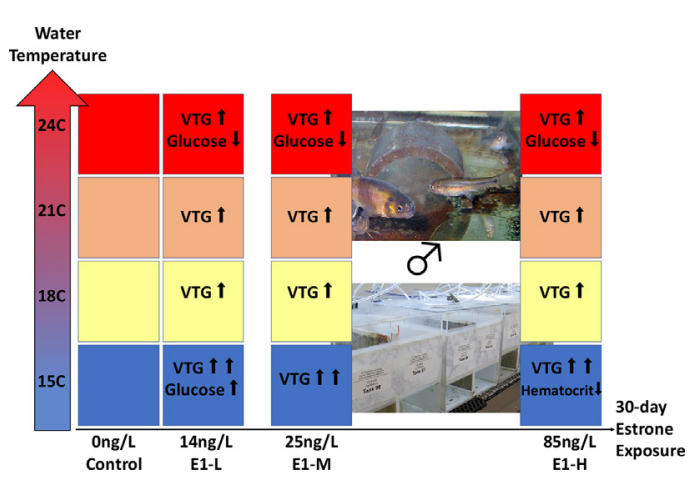

\begin{abstract}
A B S T R A C T
Environmental pollutants, including estrogens, are widespread in aquatic environments frequently as a result of treated wastewater effluent discharged. Exposure to estrogens has been correlated with disruption of the normal physiological and reproductive function in aquatic organisms, which could impair the sustainability of exposed populations. However, assessing the effects of estrogen exposure on individuals is complicated by the fact that rates of chemical uptake and environmental degradation are temperature dependent. Because annual temperature regimes often coincide with critical periods of biological activity, temperature-dependent changes in estrogen degradation efficacy during wastewater treatment could modulate biological effects. We examined the interactions between ambient water temperature and degradation of estrone (E1) during wastewater treatment. In addition, we exposed mature fathead minnows (Pimephales promelas) to three environmentally relevant concentrations of $\mathrm{E} 1$ at four different water temperatures $\left(15^{\circ} \mathrm{C}, 18^{\circ} \mathrm{C}, 21^{\circ} \mathrm{C}\right.$, and $\left.24^{\circ} \mathrm{C}\right)$ to reflect natural seasonal variation. E1 degradation occurred with and without the support of robust nitrification at all temperatures; however, the onset of $\mathrm{E} 1$ degradation was delayed at cooler water temperatures. In addition, we observed significant interactive effects between temperature and $\mathrm{E} 1$ exposure. Female morphometric endpoints were more susceptible to temperature-modulating effects while physiological endpoints were more strongly affected in males. Collectively, the data demonstrate that natural seasonal fluctuations in temperature are sufficient to affect E1 degradation during wastewater treatment and induce sex-dependent physiological and anatomical changes in exposed fish.
\end{abstract}

() 2017 Elsevier B.V. All rights reserved.

\footnotetext{
* Corresponding author at: St. Cloud State University, Aquatic Toxicology Laboratory, WSB-273, 720 Fourth Avenue South, St. Cloud, MN 56301, United States. E-mail address: hschoenfuss@stcloudstate.edu (H.L. Schoenfuss).

${ }^{1}$ Current address: Department of Biology, Ball State University 2000 W. University Avenue, Muncie, IN 47306, United States.
} 


\section{Introduction}

All vertebrates naturally excrete estrogens in their urine and feces. Among the estrogens secreted, 17 $\beta$-estradiol (E2) has received the greatest attention as a result of its presence in wastewater effluent (Kolpin et al., 2002) and estrogenic potency (Van den Belt et al., 2004). However, E2 quickly biodegrades into the more stable E1 under aerobic conditions (Vajda et al., 2008; Writer et al., 2012), which tends to be more persistent in the environment (Johnson and Williams, 2004; de Mes et al., 2005) and present at environmental concentrations frequently in the tens of ng/L and may can exceed $100 \mathrm{ng} / \mathrm{L}$ (Alvarez et al., 2013; Ankley et al., 2017; Chen et al., 2010; Matthiessen et al., 2006). Fortunately, E1 is also degraded biologically in wastewater treatment systems, with conditions that support robust nitrification also supporting E1 degradation (Shi et al., 2004; Tan et al., 2013). In addition, during nitrification at temperatures between 16 and $26{ }^{\circ} \mathrm{C}$, researchers (Suarez et al., 2010) have observed that $99 \%$ of the E1 and E2 present in the influent degraded. Nevertheless, nitrification is sensitive to temperature and researchers have also shown that both ammonia and estrogen degradation can slow dramatically with decreasing temperature (Raman et al., 2001; Wild et al., 1971). As a result, decreased water temperatures could feasibly increase estrogenic concentrations in aquatic ecosystems.

The presence of estrogens in aquatic ecosystems is correlated with disruption of the normal physiological and reproductive function of aquatic organisms. Estrogens present in municipal and industrial effluents have been causally linked to widespread sexual perturbation in exposed wild fish populations (Jobling et al., 1998; Routledge et al., 1998). Most dramatically, exposure of an experimental lake to a synthetic estrogen ( $17 \alpha$-ethynylestradiol) caused the collapse of the resident fathead minnow population (Kidd et al., 2007; Palace et al., 2009). In laboratory studies, plasma vitellogenin (VTG), an egg yolk precursor protein produced by female fish for reproduction, has been shown to be elevated in males exposed to estrogens (e.g., Hemmer et al., 2002; Shappell et al., 2010). Estrogen exposure also decreases reproductive success through reduced fecundity and fertilization success (Dammann et al., 2011; Panter et al., 1998; Parrott and Blunt, 2005; Thorpe et al., 2003).

Organisms live in dynamic environments, and abiotic environmental conditions can interact with chemical challenges to produce complex organismal responses (Brian et al., 2008). Ambient temperature exerts an environmental influence on ectothermic aquatic organisms, including teleost fish (Jin et al., 2009). However, assessing the effects of temperature and estrogenic exposure on individual aquatic organisms is complicated by the temperature dependent rates of $\mathrm{E} 1$ degradation in the environment and rates of E1 uptake by aquatic organisms (Gordon, 2003; Heugens et al., 2001; Starner et al., 1999). Established experimental protocols for toxicological experiments often fail to take abiotic environmental factors such as temperature into account (Jin et al., 2009). Most fishes, including fathead minnows, are ectothermic; therefore, water temperature has the potential to exert effects at multiple levels of organization, from gene expression and biosynthesis (e.g., the rate of VTG expression; Brian et al., 2008; Körner et al., 2008) to ecological responses (i.e., the timing of reproduction; Gillet and Quétin, 2006). Whereas temperature and environmental estrogens have been individually shown to influence the physiology and reproductive functioning of fish, the biological effects resulting from the interaction between these two factors are understudied (Jin et al., 2009; Körner et al., 2008) and are potentially complex. Because annual temperature regimes often coincide with critical periods of biological activity (i.e., reproduction during spring warming of aquatic environments), temperature-dependent changes in E1 degradation efficacy during wastewater treatment could have a dramatic impact on fish present in receiving waters.

The goals of the current study were to (i) examine the interactions between ambient water temperature and E1 degradation during wastewater treatment, and (ii) to assess the biological response in fish exposed to E1 under several temperature regimes. Specifically, we tested the hypotheses that (i) cooler water temperatures adversely affects E1 degraders and therefore E1 degradation in model wastewater treatment systems, and (ii) cooler water temperatures exacerbate the physiological and reproductive effects of E1 exposure on adult fathead minnows. Alternatively, the biological effects of E1 exposure on adult fathead minnows could be exacerbated at higher water temperatures, possibly as a result of the increased organismal metabolism, or there could be no effect of water temperature on exposed organisms. Previous studies have shown that chemical toxicants can interact with the thermal conditions in complex ways to influence physiological impairment and survival (Heugens et al., 2001; Gordon, 2003); therefore, these alternative hypotheses would account for these potential outcomes.

\section{Materials and methods}

\subsection{Experimental design}

\subsubsection{Estrone removal experiments}

Duplicate laboratory-scale nitrification experiments were performed at room temperature $\left(21 \pm 2{ }^{\circ} \mathrm{C}\right)$ (mean standard \pm deviation) for 31 days (Peterson et al., 2017) and duplicate nitrification experiments were performed at $15^{\circ} \mathrm{C}$ for 48 and 55 days. A clean water control reactor was also monitored and those results are presented elsewhere (Peterson et al., 2017). Each reactor was seeded with $10 \mathrm{~mL}$ of preserved concentrated activated sludge from the Metropolitan Wastewater Treatment Plant (Metro WWTP) in St. Paul, MN, as described elsewhere (Peterson et al., 2017). The reactors were fed with primary effluent collected from the Metro WWTP and amended with $10 \mu \mathrm{g} / \mathrm{L} \mathrm{E1}$. The high E1 concentration was chosen to allow for detailed tracking of E1 degradation without the need for large volume extraction. The influent, as described elsewhere (Peterson et al., 2017), contained the following: 299 $\pm 80 \mathrm{mg} / \mathrm{L}(\mathrm{n}=8)$ mean chemical oxygen demand, $47 \pm 7.8 \mathrm{mg} / \mathrm{L}(\mathrm{n}$ $=16)$ total nitrogen and $6.2 \pm 3.1 \mu \mathrm{g} / \mathrm{L}(\mathrm{n}=16) \mathrm{E} 1$. Reactors were operated as continuous flow systems and had a reactor volume, HRT, and SRT of $0.8 \mathrm{~L}, 5 \mathrm{~h}$, and 10 days, respectively. A cross flow filtration membrane (Spectrum Labs Minikros® 750 kDa mPES) was used as a clarifier for the laboratory-scale reactors, allowing the uncoupling of the solids residence time (SRT) from the hydraulic residence time (HRT). The membrane was backwashed as described elsewhere (Peterson et al., 2017), to avoid excessive pressure drop across the membrane. In the $15{ }^{\circ} \mathrm{C}$ experiments the reactors were maintained in a cold room (10 ${ }^{\circ} \mathrm{C}$ ) while continuously mixed on a heated stir plate. Dissolved oxygen (DO) was maintained at $>5 \mathrm{mg} / \mathrm{L}$ in the reactors throughout the experiments using a diffuser continuously feeding air. Effluent samples were analyzed for ammonia, nitrate, nitrite and E1 concentrations twice weekly.

\subsubsection{Flow-through exposure experiments}

Four successive month-long flow-through exposure experiments were conducted in the Aquatic Toxicology Laboratory at St. Cloud State University (MN) between March and July 2015. Previously published flow-through exposure protocols (Hyndman et al., 2010; Schoenfuss et al., 2008; Shappell et al., 2010) were modified to accommodate a $4 \times 4$ factorial experimental design consisting of graded concentrations of E1: low (E1-L), medium (E1-M), and high (E1-H), at 12.5, 25 , and $65 \mathrm{ng} / \mathrm{L} \mathrm{E1}$ respectively, including an ethanol control (0 ng/L E1; $0.0002 \%$ ethanol v/v) at four temperatures $\left(15^{\circ} \mathrm{C}, 18^{\circ} \mathrm{C}, 21{ }^{\circ} \mathrm{C}\right.$, and 24 $\left.{ }^{\circ} \mathrm{C}\right)$. Concentrations of E1, especially in the low and medium treatment, were chosen to be of immediate environmental relevance (Alvarez et al., 2013; Ankley et al., 2017; Chen et al., 2010; Matthiessen et al., 2006). Estrone (Sigma-Aldrich, St. Louis, MO) was dissolved in $100 \%$ ethanol to generate treatment-specific concentrated aliquots used to make fresh E1 stock solutions on every third day of the exposure period. Estrone concentrations in these concentrated aliquots were confirmed 
analytically prior to the commencement of exposures. Treatmentspecific concentrated aliquots were diluted in $10 \mathrm{~L}$ of water and pumped (Cole-Palmer Masterflex 7523-40 peristaltic pump) at a consistent rate through stainless steel tubing into a continuous flow of groundwater (100 $\mathrm{mL} / \mathrm{min} /$ aquarium) to achieve the desired exposure concentrations. A mixing tank with two internal chambers was utilized to ensure complete mixing of ground water and E1 stock solution prior to the mixture being distributed equally to all aquaria within a treatment. The final treatment specific flow rate provided approximately 12 volume exchanges per $24 \mathrm{~h}$ to assure a near constant E1 concentration in the exposure system to avoid substantial temperature-specific differences in E1 degradation across fish exposure treatments.

Mature (6 months old) fathead minnows (P. promelas) were obtained from a dedicated laboratory fish supplier (Environmental Consulting and Testing, Superior, WI). Exposures were conducted all four concentrations of $\mathrm{E} 1$ for 30 days at one temperature at a time due to facility size restrictions. A total of 28 aquaria (volume: $12 \mathrm{~L}$; dimensions: 30.5 $\times 30.5 \times 30.5 \mathrm{~cm}$ ) were divided in half by the addition of a stainlesssteel mesh partition to accommodate two breeding groups, each consisting of one male and two females ( 56 breeding groups total; 10-14 aquaria per treatment). All fish were assessed for morphological and histopathological endpoints at the end of the 30-day exposure in accordance with approved St. Cloud State University IACUC protocols (\# 8-73). Fish were maintained in accordance to US EPA guidelines (Denny, 1987), with the exception of water temperature which was adjusted to meet the experimental objectives. Fish were fed a diet of frozen blood worms (Glycera spp.) and brine shrimp (Artemia spp.) ad libitum twice daily (Brine Shrimp Direct, Ogden, UT) and maintained on a $16: 8 \mathrm{~h}$ light/dark photoperiod.

\subsection{Chemical analyses}

\subsubsection{Flow-through exposure water quality and chemistry}

Water quality parameters were recorded daily and included temperature, $\mathrm{pH}$, dissolved oxygen, conductivity, salinity, and oxidation reduction potential using a YSI (model 556 MPS; Yellow Springs, OH). Every third day total hardness, free chlorine, total chlorine, $\mathrm{pH}$ and alkalinity were screened for using AquaChek 5 in 1 test strips (Hach Company, Loveland, CO). The concentration of the $\mathrm{E} 1$ stock solution was verified using LC/MS/MS. Water sample collection occurred the day after an E1 chemical solution renewal; water samples were collected from the outflow of the mixing tanks in 1-L high density polyethylene bottles and stored at $-20^{\circ} \mathrm{C}$ until further analysis.

\subsubsection{Water chemistry analysis}

Methods for monitoring chemical oxygen demand (COD), $\mathrm{pH}$, dissolved oxygen, ammonia, total nitrogen, nitrate, and nitrite in the laboratory-scale wastewater reactors are described in detail elsewhere (Peterson et al., 2017). Briefly, COD, ammonia, and total nitrogen were measured colorimetrically. Dissolved oxygen and $\mathrm{pH}$ were measured with a Vernier optical dissolved oxygen probe and a Vernier pH sensor. Nitrate and nitrite were measured in filtered samples $(0.2-\mu \mathrm{m})$ by ion chromatography with detection limits of approximately $0.2 \mathrm{mg} / \mathrm{L}$ as nitrogen.

\subsection{E1 analysis}

Methods for sample extraction and E1 analysis are described in detail elsewhere (Peterson et al., 2017). Briefly, samples of 10-100 mL were extracted via solid phase extraction (except for concentrated treatment-specific aliquots in ethanol) after labeled surrogate $\left(13,14,15,16,17,18-{ }^{13} \mathrm{C} 6\right.$-estrone) amendment. Extracts were cleaned using a silica gel column. Extracts were blown down to dryness and resuspended in methanol:water $(60: 40, \mathrm{v} / \mathrm{v})$ and an internal standard $\left(2,4,16,16-\mathrm{D}_{4}\right.$-estrone $)$ was added before analysis. Analysis was performed on an Agilent 1100 series Liquid Chromatograph (LC) with a
4000 QTRAP triple quadrupole mass spectrometer as described elsewhere (Peterson et al., 2017). Recovery averaged $64 \pm 17 \%$. Typical limits of quantification were $11.5 \mathrm{ng} / \mathrm{LE} 1 \mathrm{sample}$ (Peterson et al., 2017).

\subsection{Biological endpoints}

\subsubsection{Plasma VTG analysis}

Heparinized capillary tubes were used for blood collection from the severed caudal vasculature of anesthetized minnows $(0.01 \%$ neutral buffered MS-222 solution; Argent Laboratories, Redmond, WA). Male fish yielded on average 50-100 $\mu \mathrm{L}$ whole blood while female fish often yielded less than half as much. Whole blood was centrifuged at 3600 $\times g$ for 5 min at $4{ }^{\circ} \mathrm{C}$, before plasma was separated and stored at -80 ${ }^{\circ} \mathrm{C}$ for subsequent analysis. Plasma volume varied substantially between fish (males: 20-50 $\mu \mathrm{L}$; females $<5-30 \mu \mathrm{L}$ ) and at times prevented vitellogenin analysis especially in female fish. However, to maintain the integrity of the experimental design, plasma samples were not pooled. Quantification of plasma VTG was achieved through a competitive antibody-capture ELISA (Parks et al., 1999) requiring a small volume of blood plasma ( $5 \mu \mathrm{L}$ ) for analysis. A two-fold serial dilution was used to prepare an eight-point standard curve ranging from $4.8 \mu \mathrm{g} / \mathrm{mL}$ to $0.00375 \mu \mathrm{g} / \mathrm{mL}$. Further elaboration of this method can be found in Parks et al. (1999) and Shappell et al. (2010).

\subsubsection{Blood glucose and hematocrit}

Blood glucose was measured using a digital glucose monitor (TRUEbalance Blood Glucose Monitor, Moore Medical, Farmington, $\mathrm{CT}$ ), which utilizes a $1 \mu \mathrm{L}$ sample of whole blood obtained from the caudal vasculature of each fish. To measure hematocrit (i.e., percent packed red blood cells), heparinized capillary tubes were used to collect whole blood. Hematocrit tubes were sealed with a clay plug and centrifuged at $3600 \times \mathrm{g}$ for $5 \mathrm{~min}$ (HERMLE Z200A, Labnet International Inc., Woodbridge, $\mathrm{NJ}$ ) before hematocrit was determined using a Spiracrit Micro-Hematocrit Tube Reader (Clay Adams Inc., New York, NY).

\subsubsection{Organosomatic indices}

Fish were euthanized using a $0.01 \%$ neutral buffered MS-222 solution (Argent Laboratories, Redmond, WA) prior to dissection. Each fish was measured for total length (TL, in $\mathrm{mm}$ ) and standard length (SL, in $\mathrm{mm}$ ) using a metric ruler and for total body weight (in grams, using a digital scale precise to $0.01 \mathrm{~g}$; Acculab Vicon, Edgewood, NY). Body condition factor (BCF), an overall measurement of fish health, was calculated using the formula $\left(B C F=\left[\right.\right.$ body weight $/$ total length $^{3}$ ] $\times 100,000$; Fulton, 1904). Liver and reproductive organs (i.e., ovaries and testes) were collected and the mass of each organ was recorded using a digital scale precise to $0.001 \mathrm{~g}$ (Mettler Toledo AG245, Columbus, OH). A hepatosomatic index value (HSI; liver weight / whole body weight $\times 100$ ) and a gonadosomatic index value (GSI; gonad weight/whole body weight $\times 100$ ) were calculated for each fish, respectively.

\subsubsection{Secondary sex characteristics}

Secondary sexual characteristics (SSC) were measured using a scoring system based on prominence of characters using a scale from 1 (least prominent) to 3 (very prominent) to score the fatty dorsal pad, tubercles, and banded coloration intensity, following methods described in Smith (1978).

\subsubsection{Histopathology}

Excised livers and gonads were placed in histological cassettes, and fixed in $10 \%$ neutral buffered formalin. Dehydration protocols described in Carson (1997) were used to process tissue samples in a Leica ASP 300 Automated Tissue Processor. Paraffin embedded tissues were sectioned on a Reichert-Jung 2030 cassette microtome ( $5 \mu \mathrm{m}$ sections). Tissues were stained with hematoxylin and eosin counter-stain procedures described in Carson (1997) using a Leica ST5010 Autostainer XL. Liver hepatocyte vacuolization and developmental stage were assessed using 
bright-field microscopy. Liver vacuolization was based on the prominence of vacuoles in hepatocytes within the field of view, 1 (few vacuoles visible), 2, (small vacuoles visible throughout the tissue section), 3 , (vacuoles prominent and widespread), and 4, vacuoles large and the dominating feature of the tissue sections) (Fig. S1). Reproductive maturity was based on the percentage of four main germ cell types during gametogenesis (i.e., spermatogenesis and oogenesis) within the field of view (Fig. S2). The presence of pathologies such as eosinic fluid or intersex were noted when observed during evaluation. The assessment of four to six histological sections was blinded with the observer unaware of the treatment of each observed section.

\subsection{Data analysis}

Males and females were analyzed separately using multivariate analysis of variance (MANOVA) with concentration, temperature, and concentration $\times$ temperature specified as fixed factors and SL, body weight, gonad weight, liver weight, hematocrit, blood glucose level, plasma VTG concentration, BCF, GSI, and HSI specified as dependent variables. Dependent variables were log transformed where needed to improve normality. The model for males also included an overall SSC score for each male, based on the degree of development of the tubercles and dorsal pad, and the intensity of banding color. Preliminary analysis revealed that these characters were highly correlated; therefore, each male was assigned a SSC score based on principal components analysis (PCA). The PCA extracted a single component that explained $68 \%$ of the variation. Where appropriate, pair-wise post hoc tests (Least Significant Difference; LSD) were used to compare dependent variables across levels for significant effects. All analyses were conducted using SPSS (v21), apart from the multiple comparisons analysis for the histological data, which utilized a two-way ANOVA using Prism 6.1A Graph-Pad Software, followed by Tukey's multiple comparisons post hoc test. Calibration curves for E1, ${ }^{13} \mathrm{C}$-labeled E1, nitrite, nitrate and COD were generated from a simple linear regression of the samples in either Excel or R. Reported P-values were generated with R software utilizing a two sample, two-sided, un-pooled Student's $t$-test.

\section{Results}

\subsection{E1 removal experiments}

Results from the nitrification experiments performed at room temperature are shown in Fig. 1, with complete ammonia oxidation to nitrate occurring by Day 20 in the duplicate experiments (also see Peterson et al., 2017). Delayed onset of nitrification was observed in the $15^{\circ} \mathrm{C}$ experiment, as expected, with complete ammonia oxidation to nitrate occurring by Days 36 and 40 in the duplicate experiments (Fig. 1). E1 removal was excellent in all experiments, with effluent E1 concentrations of $257 \pm 112 \mathrm{ng} / \mathrm{L}(0.26 \pm 0.11 \mu \mathrm{g} / \mathrm{L})$ after Day 3 in the room temperature experiments and $58 \pm 38 \mathrm{ng} / \mathrm{L}(0.06 \pm 0.04 \mu \mathrm{g} / \mathrm{L})$ after Day 10 in the $15{ }^{\circ} \mathrm{C}$ experiments. These concentrations are slightly higher, but within the same order of magnitude as the concentrations used in the minnow exposure experiments. The onset of E1 degradation was delayed approximately 3 days, however, though only slightly compared to the onset of nitrification, which was delayed approximately 25-30 days in the $15^{\circ} \mathrm{C}$ experiments (Fig. 1 ).

\subsection{Flow-through exposure experiments water quality and E1 concentrations}

Environmental conditions were stable throughout the duration of all four temperatures (Table 1). Verification of concentrated treatmentspecific E1 aliquots in ethanol confirmed concentrations near the target values for the concentrated stock solutions (E1-L: nominal E1 concentrated aliquot concentration $67.5 \mu \mathrm{g} / \mathrm{mL}$, measured $62.9 \mu \mathrm{g} / \mathrm{mL}$; E1-M: $337.5 \mu \mathrm{g} / \mathrm{mL}$, measured $290 \mu \mathrm{g} / \mathrm{mL}$; E1-H: $1687.5 \mu \mathrm{g} / \mathrm{mL}$, measured

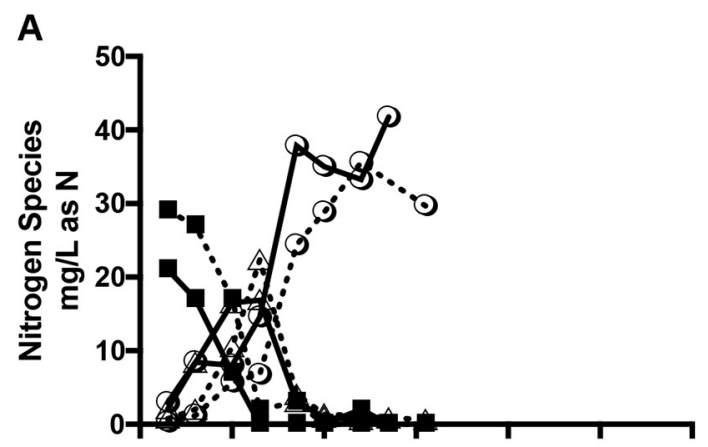

B

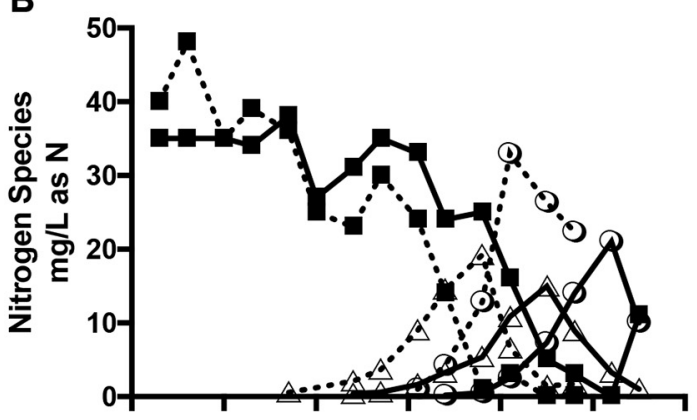

C

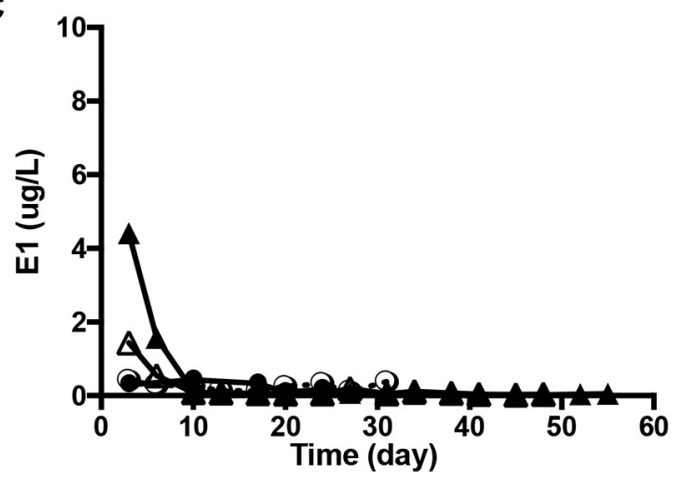

Fig. 1. Comparison of ammonium, nitrite, nitrate, and E1 concentrations over time in the laboratory-scale wastewater reactors. Panel A shows reactor performance in terms of nitrogen speciation at room temperature, Panel B shows reactor performance at $15^{\circ} \mathrm{C}$. Here dotted lines and solid lines show data from replicate experiments. In Panels A and $B$, closed squares $(\square)$ are ammonium, open circles $(O)$ are nitrate, and open triangles $(\Delta)$ are nitrite. Panel C shows E1 transformation in the two reactors, with the open $(\Delta)$ and closed triangles $(\boldsymbol{\Delta})$ representing E1 concentration in the duplicate $15^{\circ} \mathrm{C}$ reactors and the open $(O)$ and closed circles $(\bullet)$ representing E1 concentration in the duplicate room temperature reactors.

$1435 \mu \mathrm{g} / \mathrm{mL}$ ). Collapsing over all concentrations, environmental conditions are as follows: $15^{\circ} \mathrm{C}$ experiment: $\mathrm{pH}=7.9 \pm 0.3$; conductivity $=0.90 \pm 0.04$; salinity $=0.45 \pm 0.02 ; \mathrm{ORP}=225.3 \pm 64.5 ; 18{ }^{\circ} \mathrm{C} \mathrm{ex}-$ periment: $\mathrm{pH}=7.7 \pm 0.2$; conductivity $=0.90 \pm 0.07$; salinity $=0.45$ \pm 0.01 ; ORP $=266.9 \pm 22.5 ; 21{ }^{\circ} \mathrm{C}$ experiment: $\mathrm{pH}=8.14 \pm 0.2$; conductivity $=0.63 \pm 0.42$; salinity $=0.31 \pm 0.21 ;$ ORP $=167.5 \pm$ 38.0; and $24{ }^{\circ} \mathrm{C}$ experiment: $\mathrm{pH}=7.72 \pm 0.3$; conductivity $=0.92 \pm$ 0.07 ; salinity $=0.46 \pm 0.01 ; \mathrm{ORP}=125.3 \pm 0.28$. E1 measured concentrations were $14.26 \pm 3.1,25.43 \pm 9.3$ and $84.83 \pm 40.4 \mathrm{ng} / \mathrm{L}$ for the $\mathrm{E} 1-$ $\mathrm{L}(\mathrm{n}=7), \mathrm{E} 1-\mathrm{M}(\mathrm{n}=8)$ and $\mathrm{E} 1-\mathrm{H}(\mathrm{n}=11)$ treatments respectively (Table 1).

\subsubsection{Fish survival}

In total, 642 fish (428 females and 214 males) were analyzed for the experiment. Fish survival across all thermal regimes was excellent (range: 92-99\%) and similar when compared across all 16 treatments using a chi-square test of independence $\left(\chi^{2}=0.99\right.$, df $=14, \mathrm{P}=$ $0.95)$. Collapsing across all concentrations, percent survival was observed to be the lowest in the $24{ }^{\circ} \mathrm{C}$ temperature exposure at $92 \%$. 
Table 1

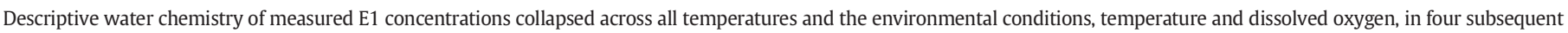
30-day exposure experiments with mature fathead minnows (mean \pm SD shown for all measured parameters with number of samples in parenthesis).

\begin{tabular}{|c|c|c|c|c|}
\hline Treatment (abbreviation) & Measured E1 concentration (ng/L) & Nominal temperature $\left({ }^{\circ} \mathrm{C}\right)$ & Measured temperature $\left({ }^{\circ} \mathrm{C}\right)$ & Measured dissolved oxygen $(\mathrm{mg} / \mathrm{L})$ \\
\hline \multirow[t]{4}{*}{ Ethanol control (EtOH) } & No E1 detected & 15 & $16.8 \pm 0.572(31)$ & $9.73 \pm 1.35(31)$ \\
\hline & & 18 & $18.9 \pm 0.722(33)$ & $7.97 \pm 1.53(33)$ \\
\hline & & 21 & $21.2 \pm 0.561(20)$ & $7.19 \pm 0.02(2)$ \\
\hline & & 24 & $24.5 \pm 0.524(31)$ & $6.95 \pm 0.24(31)$ \\
\hline \multirow[t]{4}{*}{ E1 low (E1-L) } & $14.26 \pm 3.01(7)$ & 15 & $17.2 \pm 0.761(31)$ & $9.19 \pm 1.29(31)$ \\
\hline & & 18 & $18.5 \pm 0.432(34)$ & $8.77 \pm 1.14(34)$ \\
\hline & & 21 & $21.2 \pm 0.492(20)$ & $6.99 \pm 0.00$ \\
\hline & & 24 & $24.2 \pm 0.590(31)$ & $7.71 \pm 0.21(31)$ \\
\hline \multirow[t]{4}{*}{ E1 medium (E1-M) } & $25.43 \pm 9.31(8)$ & 15 & $16.8 \pm 0.745(31)$ & $9.62 \pm 0.95(31)$ \\
\hline & & 18 & $18.7 \pm 0.532(34)$ & $7.97 \pm 1.31(34)$ \\
\hline & & 21 & $21.0 \pm 0.561(20)$ & $6.29 \pm 0.00(1)$ \\
\hline & & 24 & $24.3 \pm 0.591(31)$ & $7.71 \pm 0.21(31)$ \\
\hline \multirow[t]{4}{*}{ E1 high $(\mathrm{E} 1-\mathrm{H})$} & $84.83 \pm 40.54(11)$ & 15 & $16.5 \pm 0.459(30)$ & $10.12 \pm 1.23(30)$ \\
\hline & & 18 & $18.3 \pm 0.318(34)$ & $8.78 \pm 1.24(34)$ \\
\hline & & 21 & $21.1 \pm 0.594(20)$ & $6.66 \pm 0.00$ \\
\hline & & 24 & $24.3 \pm 0.597(31)$ & $7.71 \pm 0.28$ \\
\hline
\end{tabular}

Collapsing across all temperatures, the E1-M concentration had the lowest percent survival at $95 \%$.

\subsubsection{Physiological and anatomical endpoints for males and females}

For both male and female subjects, the MANOVA models revealed significant overall effects of $\mathrm{E} 1$ exposure, temperature, and concentration $\times$ temperature on organismal endpoints (Table 2 ).

3.2.2.1. Effects of E1 exposure on male organismal endpoints. There were significant effects of E1 exposure on plasma VTG concentrations in male fathead minnows $\left(\mathrm{F}_{3,169}=15.85 ; \mathrm{P}<0.001\right.$; Fig. $\left.2 \mathrm{~A}\right)$ with lower concentration in control males (E1-L, E1-M, and E1-H; all Ps < 0.001). Significant effects of E1 concentration on blood glucose $\left(F_{3,169}=5.10\right.$; $\mathrm{P}=0.002$; Fig. $2 \mathrm{~B})$ and hematocrit $\left(\mathrm{F}_{3,169}=4.88 ; \mathrm{P}=0.003\right)$ were also observed. Blood glucose levels were higher in males exposed to E1-L than in males exposed to either E1-M or E1-H $(\mathrm{P}<0.001)$. Hematocrit was significantly lower in E1-H exposed males compared with control $(\mathrm{P}=0.037)$ and $\mathrm{E} 1-\mathrm{L}(\mathrm{P}<0.001)$ exposed males, and lower in males exposed to E1-M than E1-L $(\mathrm{P}=0.013)$.

3.2.2.2. Effects of temperature on male organismal endpoints. Temperature had a significant effect on plasma VTG concentration in males $\left(\mathrm{F}_{3,169}=\right.$

Table 2

Summary of significant results for the independent and interactive biological effects of temperature and E1 exposure on exposed male and female fathead minnows relative to the ethanol carrier control. The direction of arrows indicates worsening effects as temperature or concentration, respectively, increases. For example, the induction of plasma vtg in male fathead minnows is greater at colder temperatures (second column) and at higher concentrations (3rd column).

\begin{tabular}{|c|c|c|c|c|c|c|}
\hline & \multicolumn{3}{|l|}{ MALES } & \multicolumn{3}{|c|}{ FEMALES } \\
\hline & Temp. & Conc. & $\begin{array}{l}\text { Temp } \times \\
\text { Conc }\end{array}$ & Temp. & Conc. & $\begin{array}{l}\text { Temp } \times \\
\text { Conc. }\end{array}$ \\
\hline \multicolumn{7}{|l|}{ Physiological endpoint } \\
\hline Plasma vtg & $\downarrow$ & $\uparrow$ & $\downarrow$ & & & \\
\hline Blood glucose & $\downarrow$ & $\downarrow$ & $\downarrow$ & & & $\downarrow$ \\
\hline Hematocrit & & $\downarrow$ & & & $\downarrow$ & \\
\hline \multicolumn{7}{|l|}{ Morphological endpoint } \\
\hline SL & & & & $\downarrow$ & & $\downarrow$ \\
\hline Total weight & & & & $\downarrow$ & $\downarrow$ & $\downarrow$ \\
\hline Liver weight & $\downarrow$ & & & $\downarrow$ & $\downarrow$ & $\downarrow$ \\
\hline Gonad weight & $\downarrow$ & & & $\downarrow$ & & \\
\hline $\mathrm{BCF}$ & $\downarrow$ & & & $\downarrow$ & $\downarrow$ & \\
\hline HSI & & & & $\downarrow$ & & $\downarrow$ \\
\hline GSI & $\downarrow$ & & & $\downarrow$ & & \\
\hline Vacuolization severity & $\downarrow$ & & & $\downarrow$ & & \\
\hline Mature sex cells & & $\downarrow$ & & $\downarrow$ & & \\
\hline SSC & $\uparrow$ & & & - & & - \\
\hline
\end{tabular}

$5.17, \mathrm{P}=0.002$; Fig. $2 \mathrm{~A})$ with VTG concentrations higher at $15^{\circ} \mathrm{C}$ than at $18{ }^{\circ} \mathrm{C}(\mathrm{P}=0.018)$ or $21{ }^{\circ} \mathrm{C}(\mathrm{P}<0.001$; Fig. $2 \mathrm{~B})$. Temperature also had a significant effect on blood glucose levels $\left(\mathrm{F}_{3,169}=5.10, \mathrm{P}=0.002\right)$, subjects maintained at $24{ }^{\circ} \mathrm{C}$ had significantly lower blood glucose levels compared to subjects maintained at cooler temperatures (vs $15{ }^{\circ} \mathrm{C}$ : P $=0.046 ; 18^{\circ} \mathrm{C}: \mathrm{P}=0.017 ; 21^{\circ} \mathrm{C}: \mathrm{P}=0.001$ ).

Temperature also had significant independent effects on morphological indices with greater values at lower temperatures. Significant effects of temperature were observed for male gonad weight $\left(\mathrm{F}_{3,170}=\right.$ 5.12, $\mathrm{P}=0.002)$ and liver weight $\left(\mathrm{F}_{3,169}=13.96, \mathrm{P}<0.001\right)$. Gonad weight at $15^{\circ} \mathrm{C}$ was significantly greater than at $21{ }^{\circ} \mathrm{C}(\mathrm{P}=0.001)$ or $24^{\circ} \mathrm{C}(\mathrm{P}=0.008)$. Liver weights were higher at the two lowest temperatures $\left(15^{\circ} \mathrm{C}\right.$ and $\left.18{ }^{\circ} \mathrm{C}\right)$ than they were at either of the two higher temperatures $\left(21{ }^{\circ} \mathrm{C}\right.$ and $24{ }^{\circ} \mathrm{C}$ ) (all Ps $<0.003$ ). Significant effects of temperature on $\mathrm{BCF}(\mathrm{P}=0.002)$ and $\mathrm{GSI}(\mathrm{P}<0.001)$ were also observed. Post hoc analysis showed that the body condition of males maintained at the highest temperature $\left(24^{\circ} \mathrm{C}\right)$ was significantly reduced compared to that of males maintained at lower temperatures $\left(15^{\circ} \mathrm{C}: \mathrm{P}=0.011 ; 18\right.$ $\left.{ }^{\circ} \mathrm{C}: \mathrm{P}=0.027 ; 21{ }^{\circ} \mathrm{C}: \mathrm{P}=0.009\right)$. The average $\mathrm{GSI}$ was greater at $15^{\circ} \mathrm{C}$ than at any of the higher temperatures $(0.032 \leq$ Ps $<0.001)$. There was a significant effect of temperature on the degree of development of male SSC $\left(\mathrm{F}_{3,169}=4.59, \mathrm{P}=0.004\right)$. Post hoc tests indicated that male SSC scores were higher at $24^{\circ} \mathrm{C}$ than at $15^{\circ} \mathrm{C}(\mathrm{P}=0.005)$. An extremely significant effect of temperature was observed for male vacuolization severity for liver histology $\left(\mathrm{F}_{3,250}=10.02, \mathrm{P}<0.0001\right)$. Males maintained at cooler temperatures $\left(15^{\circ} \mathrm{C}\right.$ and $\left.18{ }^{\circ} \mathrm{C}\right)$ displayed higher levels of liver vacuolization severity than males maintained at $21^{\circ} \mathrm{C}$ and $24{ }^{\circ} \mathrm{C}$.

3.2.2.3. Interactions between E1 exposure and temperature on male organismal endpoints. A significant interaction between water temperature and E1 exposure concentration was observed for plasma VTG concentration $\left(\mathrm{F}_{9,170}=2.99, \mathrm{P}=0.002\right)$; in general, the differences in plasma VTG concentration between control and exposed males was more pronounced at cooler temperatures. Post hoc analysis showed that plasma VTG levels were significantly reduced in control males compared to exposed males at temperatures $15^{\circ} \mathrm{C}, 18{ }^{\circ} \mathrm{C}$, and $21^{\circ} \mathrm{C}(0.034 \leq \mathrm{Ps}<0.001$; Fig. 2A). A significant temperature $\times$ concentration interaction was also observed for blood glucose $\left(\mathrm{F}_{9,169}=3.74, \mathrm{P}<0.001\right.$; Fig. $\left.2 \mathrm{~B}\right)$. Post hoc tests revealed that control and E1-L males maintained at $18{ }^{\circ} \mathrm{C}$ had significantly elevated blood glucose compared to E1-M and E1-H exposed males, in addition to males at $24{ }^{\circ} \mathrm{C}$ (control vs E1-L; Fig. 2B).

3.2.2.4. Effects of E1 exposure on female organismal endpoints. Female endpoints were not nearly as impacted by exposure as those of males; however, a statistically significant effect of E1 exposure on hematocrit $\left(F_{3,215}=2.95, \mathrm{P}=0.034\right)$ was observed, and post hoc tests revealed 
(A)

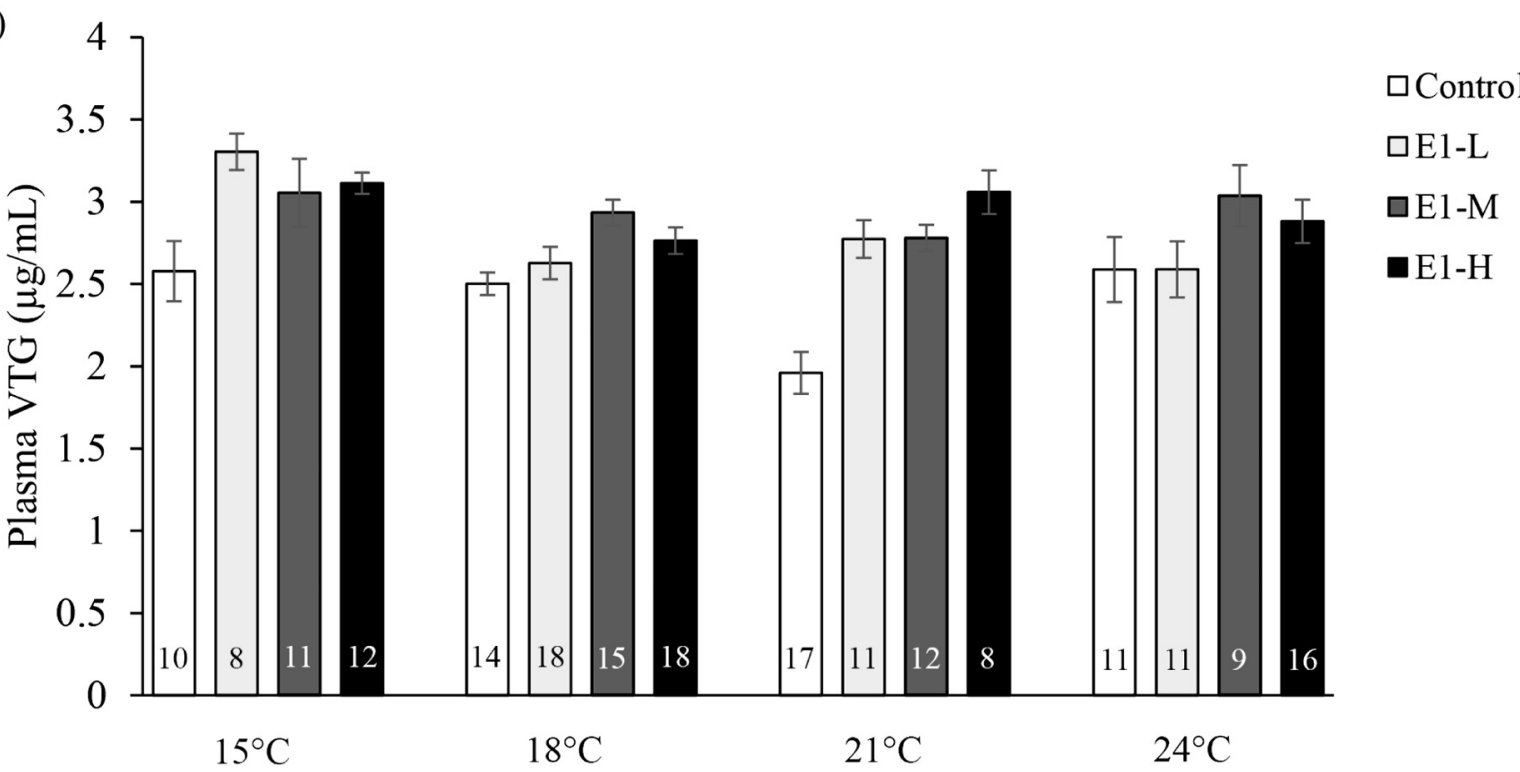

(B)

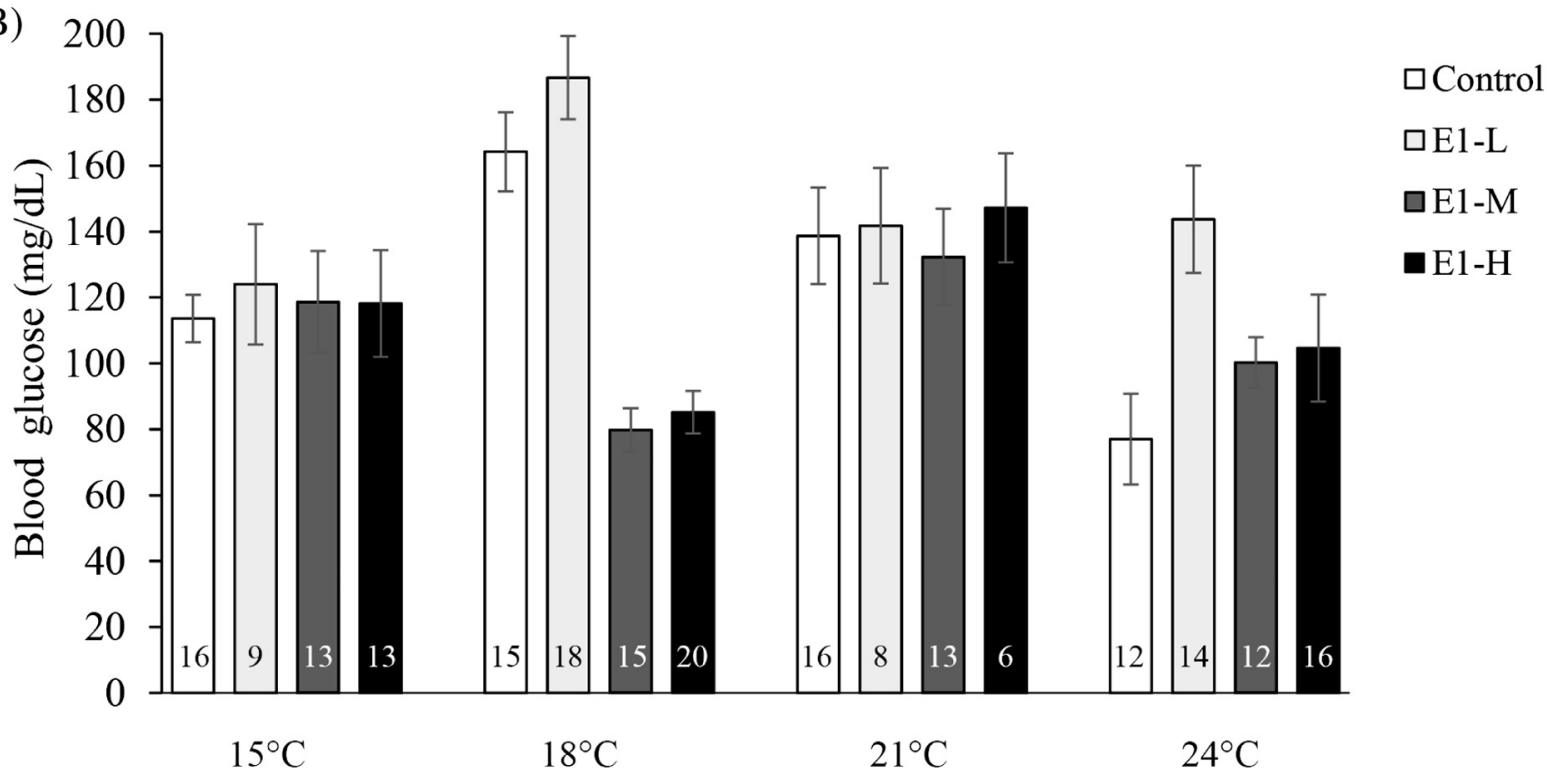

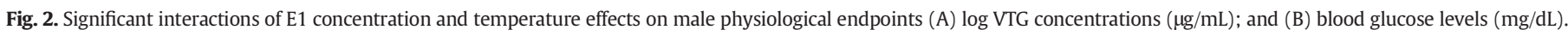

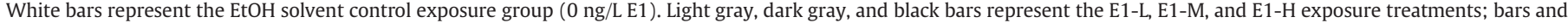
error bars depict means \pm SEM.

the hematocrit of control females was greater than E1-H exposed females $(P=0.015)$. In contrast to the results for males, however, female morphology was affected by E1 exposure (Fig. 4). In particular, significant effects of E1 concentration were observed on female fish total weight $\left(F_{3,215}=4.64, \mathrm{P}=0.004\right)$ and liver weight $\left(\mathrm{F}_{3,215}=5.71, \mathrm{P}=\right.$ 0.001 ). Post hoc tests indicated that the weights of females exposed to E1-M had a significantly reduced total weight compared to females exposed to $\mathrm{E} 1-\mathrm{L}(\mathrm{P}=0.024)$. In addition, the liver weights of fish exposed to E1-M were less than the liver weights of control fish $(P=0.030)$ and fish exposed to $\mathrm{E} 1-\mathrm{L}(\mathrm{P}=0.007)$. Significant effects of $\mathrm{E} 1$ concentration were observed for $\mathrm{BCF}\left(\mathrm{F}_{3,215}=3.66, \mathrm{P}=0.013\right)$ and $\mathrm{HSI}\left(\mathrm{F}_{3,215}=3.42\right.$, $\mathrm{P}=0.018)$. The $\mathrm{BCF}$ of subjects exposed to $\mathrm{E} 1-\mathrm{M}$ was reduced compared with that of fish exposed to E1-L $(\mathrm{P}=0.01)$.

3.2.2.5. Effects of temperature on female organismal endpoints. A significant effect of temperature was observed in female fish for SL $\left(F_{3,215}=15.24, P<0.001\right.$; Fig. $\left.4 A\right)$, total weight $\left(F_{3,215}=\right.$ 28.28, $\mathrm{P}<0.001$; Fig. 4B), gonad weight $\left(\mathrm{F}_{3,215}=6.99, \mathrm{P}<0.001\right)$, liver weight $\left(\mathrm{F}_{3,215}=25.64, \mathrm{P}<0.001\right.$; Fig. $\left.4 \mathrm{C}\right), \mathrm{BCF}\left(\mathrm{F}_{3,215}=\right.$ 6.88, $\mathrm{P}<0.001)$, GSI $\left(\mathrm{F}_{3,215}=9.09, \mathrm{P}<0.001\right)$, and HSI $\left(\mathrm{F}_{3,215}=\right.$ 12.95, $\mathrm{P}<0.001$; Fig. 4D). Female fish maintained at $15{ }^{\circ} \mathrm{C}$ and $18{ }^{\circ} \mathrm{C}$ had bigger gonads (by weight) compared with those maintained at $21{ }^{\circ} \mathrm{C}(\mathrm{P}=0.03$ and $\mathrm{P}=0.005$, respectively $)$, and at $18{ }^{\circ} \mathrm{C}$ compared to $24{ }^{\circ} \mathrm{C}(\mathrm{P}=0.008)$. Females maintained at the coldest temperature $\left(15^{\circ} \mathrm{C}\right.$ ) had a greater $\mathrm{BCF}$ and a higher GSI than those maintained at the highest temperature $\left(24^{\circ} \mathrm{C}\right.$; all Ps $\left.<0.001\right)$. Females maintained in cooler water also had greater HSI values; HSI was higher at $15^{\circ} \mathrm{C}$ and $18{ }^{\circ} \mathrm{C}$ compared to at $21{ }^{\circ} \mathrm{C}$ (Ps $\left.<0.001\right)$ and greater at $18{ }^{\circ} \mathrm{C}$ than $24{ }^{\circ} \mathrm{C}(\mathrm{P}=0.023)$. A significant effect of temperature was evident for liver vacuolization severity in females $\left(\mathrm{F}_{3,277}=8.28, \mathrm{P}<\right.$ 0.0001 ) with vacuolization most severe in females maintained at $15{ }^{\circ} \mathrm{C}$ compared to females maintained at $24{ }^{\circ} \mathrm{C}(\mathrm{P}=0.025)$. Female sexual maturity was decreased at higher temperatures $\left(24^{\circ} \mathrm{C}\right) \mathrm{com}-$ pared to lower temperatures $\left(15^{\circ} \mathrm{C}\right)$. Significant independent effects of temperature were evident throughout all the anatomical endpoints tested, with TL being the only exception to this pattern. 
3.2.2.6. Interactions between E1 exposure and temperature on female organismal endpoints. A significant temperature $\times$ concentration interaction was detected for female blood glucose $\left(\mathrm{F}_{9,215}=2.43, \mathrm{P}=0.012\right.$; Table 2). At $18{ }^{\circ} \mathrm{C}$, subjects exposed to E1-L had higher blood glucose levels than those exposed to E1-M $(\mathrm{P}<0.001)$ or E1-H $(\mathrm{P}<0.001)$ (Fig. 3).

Interactive effects of exposure concentration and temperature were observed for female morphological indices such as $\mathrm{SL}\left(\mathrm{F}_{9,215}=3.07, \mathrm{P}=\right.$ 0.002; Fig. 4A), total weight $\left(\mathrm{F}_{9,215}=2.35, \mathrm{P}=0.015\right.$; Fig. 4B), liver weight $\left(\mathrm{F}_{9,215}=3.23, \mathrm{P}=0.001\right.$; Fig. $\left.4 \mathrm{C}\right)$, and $\mathrm{HSI}\left(\mathrm{F}_{9,215}=2.78, \mathrm{P}=\right.$ 0.004; Fig. 4D) (Table 2). Post hoc tests indicated that at $15{ }^{\circ} \mathrm{C}$ females exposed to E1-L were shorter than those in the E1-M $(\mathrm{P}<0.001)$ or $\mathrm{E} 1-\mathrm{H}(\mathrm{P}=0.03)$ treatments (Fig. $4 \mathrm{~A})$. At $21^{\circ} \mathrm{C}$ and $24^{\circ} \mathrm{C}$ fish exposed to varying concentrations of E1 were similar in size. Differences among the exposure groups in body weight were more pronounced at cooler temperatures. At $15{ }^{\circ} \mathrm{C}$, females exposed to E1-L were heavier (by weight) than fish in the control $(\mathrm{P}=0.015)$, E1-M $(\mathrm{P}<0.001)$, or $\mathrm{E} 1-\mathrm{H}(\mathrm{P}=0.014)$ groups. At $18{ }^{\circ} \mathrm{C}$, control fish also weighed more than fish exposed to $\mathrm{E} 1-\mathrm{M}(\mathrm{P}<0.001)$ or $\mathrm{E} 1-\mathrm{H}(\mathrm{P}=0.023)$ (Fig. 4B). Liver weight was negatively and approximately linearly correlated to exposure concentration at $18{ }^{\circ} \mathrm{C}$; control females had livers that were significantly heavier than females exposed to E1-M $(\mathrm{P}<0.001)$ and E1-H $(P<0.005)$, females exposed to E1-L had heavier livers than those exposed to E1-M ( $\mathrm{P}=0.001)$, and females exposed to $\mathrm{E} 1-\mathrm{M}$ had heavier livers than those exposed to $\mathrm{E} 1-\mathrm{H}(\mathrm{P}=0.025)$ (Fig. 4C). Similarly, control and E1-L exposed fish at $18^{\circ} \mathrm{C}$ also had higher HSI values than fish exposed to E1-M or E1-H $(0.037<\mathrm{P}<0.001)$ (Fig. 4D). Plasma VTG concentrations for females exposed to alternative concentrations of E1 were not dependent on temperature, suggesting that temperature does not modulate plasma VTG synthesis in exposed females, when compared to unexposed females. Collectively, the results for females suggest that temperature interacts with $\mathrm{E} 1$ exposure more intimately concerning morphological endpoints rather than physiological endpoints.

\section{Discussion}

This study examined the extent to which ambient water temperature modulates the physiological and reproductive effects of E1 exposure on adult fathead minnows. In addition, we investigated how cooler water temperature affects E1 degradation rates during wastewater treatment. The results revealed three key findings. First, E1 exposure concentration and water temperature exerted significant independent effects on fish physiology and morphology in both sexes. Cumulatively, the data suggest that temperature is the main driving force affecting morphological indices, whereas E1 exposure concentration primarily affects physiological endpoints. Second, we found evidence supporting the hypothesis that water temperature modulates the effects of

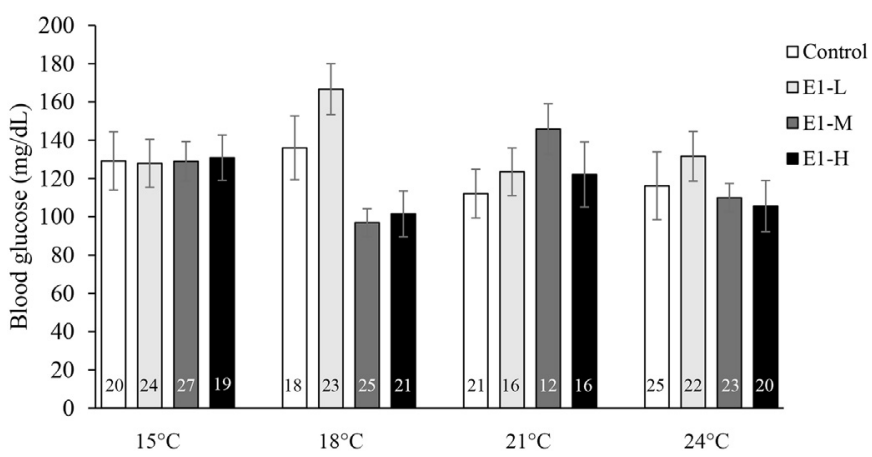

Fig. 3. Significant interaction of E1 concentration and temperature effect on female blood glucose levels $(\mathrm{mg} / \mathrm{dL})$. White bars represent the EtOH solvent control exposure group ( $0 \mathrm{ng} / \mathrm{L} \mathrm{E1}$ ). Light gray, dark gray, and black bars represent the E1-L, E1-M, and E1-H exposure treatments; bars and error bars depict means \pm SEM. estrogen exposure on both males and females, with the effects of exposure more pronounced at cooler water temperatures. Third, extensive E1 degradation was found to occur both with and without the support of efficient nitrification at all temperatures corroborating results from prior studies.

Temperature increases the metabolic rate of ectotherms (Johnston and Dunn, 1987), subsequently increasing the rate of enzymatic activity (Voet et al., 2013). Enzymes are required for hepatic synthesis of the VTG protein (Hadley and Levine, 2006). In males, the presence of VTG in the blood, and related transcription in the liver, are considered to be specific biomarkers for estrogen-mimetic contaminants in the environment (Hoyt et al., 2003). Research on salmonid fishes injected with a natural steroid estrogen has suggested that estrogenic potency increases with temperature (Korsgaard et al., 1986). However, the results of this study demonstrated an opposite phenomenon. Unexposed males did exhibit lower plasma VTG concentrations than exposed males (Fig. $2 \mathrm{~A}$ ) but male fish maintained at $15^{\circ} \mathrm{C}$ had higher concentrations of plasma VTG induction than males maintained at $18{ }^{\circ} \mathrm{C}$ or $21^{\circ} \mathrm{C}$. Further, VTG levels were significantly elevated in exposed males compared with control males only at the cooler water temperatures. The high volume turnover rates in the flow-through exposure system make it unlikely that high temperatures dramatically reduced E1 bioavailability (Raman et al., 2001) to exposed fathead minnows. Instead, males experiencing higher water temperatures may forgo vitellogenesis in order to maintain homeostasis at a higher metabolic demand (Luquet and Watanabe, 1986). This hypothesis is supported by the reduced blood glucose concentrations in E1 exposed male fish at higher temperatures (Fig. 2B) suggesting limited energetic reserves needed for VTG biosynthesis.

By contrast, we did not detect significant independent effects of exposure or interactive effects of exposure and temperature on plasma VTG induction in females (Fig. 3). Watanabe et al. (2007) pooled six large exposure studies and systematically evaluated several experimental endpoints (i.e. E2 concentrations, plasma VTG concentrations) to determine baseline natural variability in fathead minnows. They determined that the mean concentration of E2 in unexposed females was $6.07 \pm 4.0 \mathrm{ng} / \mathrm{mL}$, whereas the mean concentration of E2 in unexposed males was $0.43 \pm 0.30 \mathrm{ng} / \mathrm{mL}$. Because females naturally produce estrogens, the concentrations used for this experiment may have been insufficient to elicit a biological exposure response.

Hematological endpoints can shed insight on fish tolerance to a stressor, such as thermal stress, and the overall physiological state of the organism (Del Río Zaragoza et al., 2008). Temperature increases induce hepatic glycogenesis and glucose concentration in the blood (Radhakrishnaiah and Parvatheswararao, 1984). Temperature-induced insulin fluctuations may be correlated to changes in insulin receptor internalization and turnover rate in hepatic tissue (Larsen et al., 2001); in addition, insulin receptor binding affinity is thought to be positively correlated with increased temperatures (Freychet et al., 1971). Ekman et al. (2008) examined the biochemical effects of $17 \alpha$-ethynylestradiol exposure on male fathead minnow metabolites and found that glycogen, the stored form of glucose, was decreased in both exposure groups. The results of that study suggested that glycogen-derived glucose is an important component of meeting the energetic demands of estrogen exposed individuals, but may become depleted under intense physical demands. A similar phenomenon was observed in the current study in which unexposed males and females, or males and females exposed to E1-L, displayed higher blood glucose levels when maintained at lower temperatures than E1-M or E1-H exposed individuals, with few exceptions. This may indicate that individuals displaying higher levels of glucose can combat physiological stress, maintaining metabolic homeostasis more readily than their heavily exposed counterparts. However, the ability to buffer the effects of metabolic stress induces by VTG synthesis in male fish may not be limitless. The increased blood glucose concentrations in E1-L exposed males at lower temperatures co-occurred with a significant increase in hepatocyte vacuolization suggesting an 
(A)

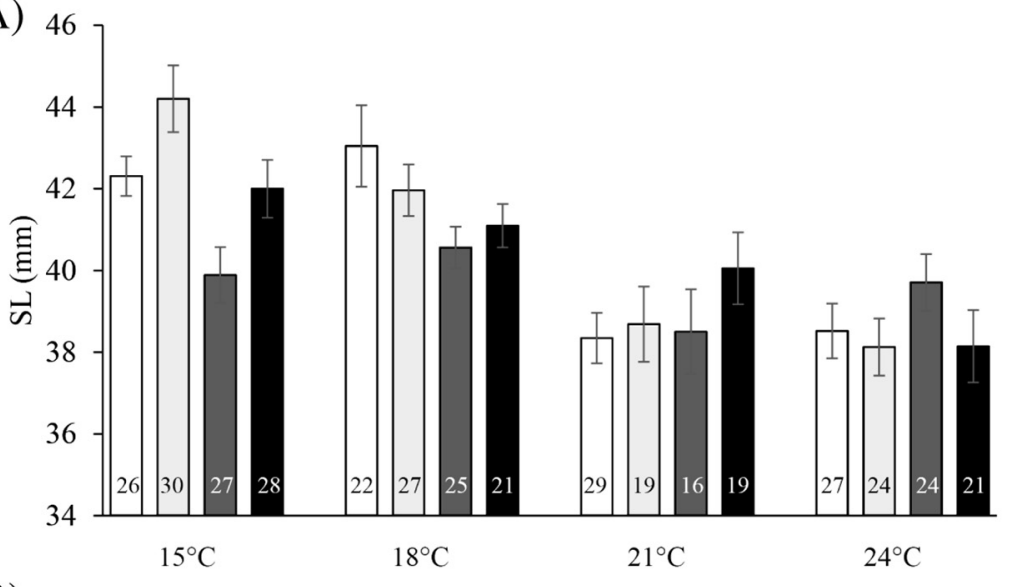

(B)

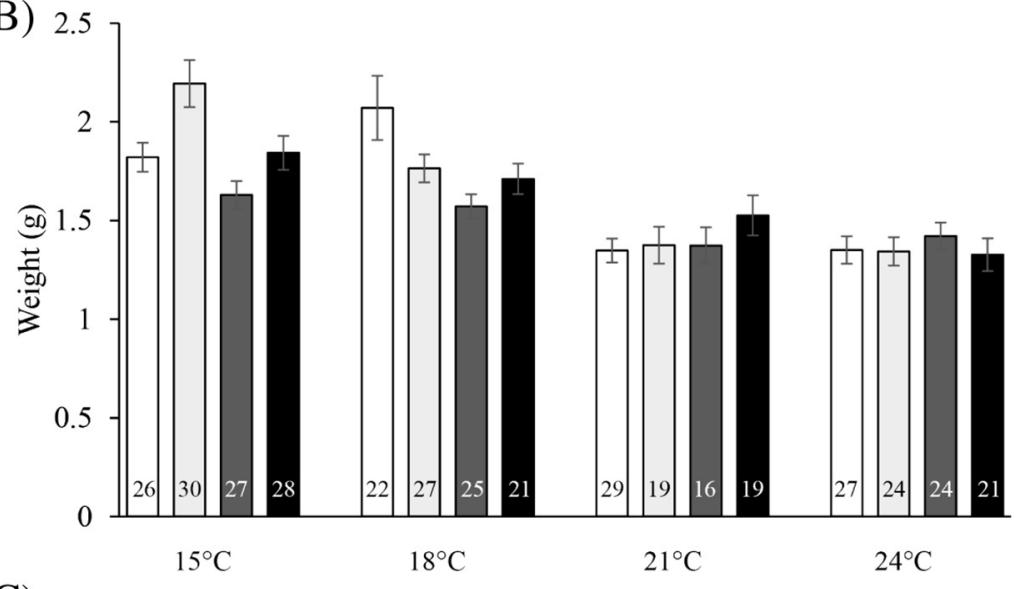

Control

$\square$ E1-L

口El-M

-E1-H

(C)

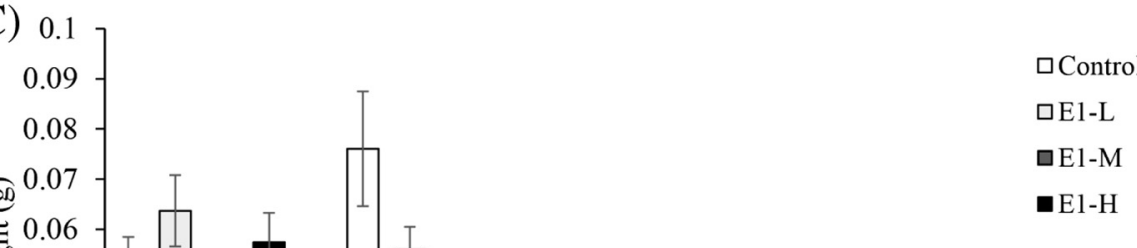

口Control 口E1-L

$\square \mathrm{E} 1-\mathrm{M}$

-E1-H

E1-L

El-H

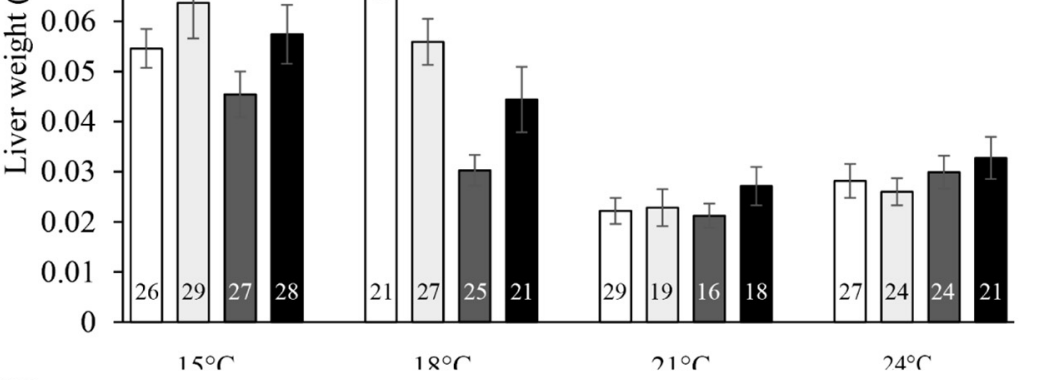

(D)

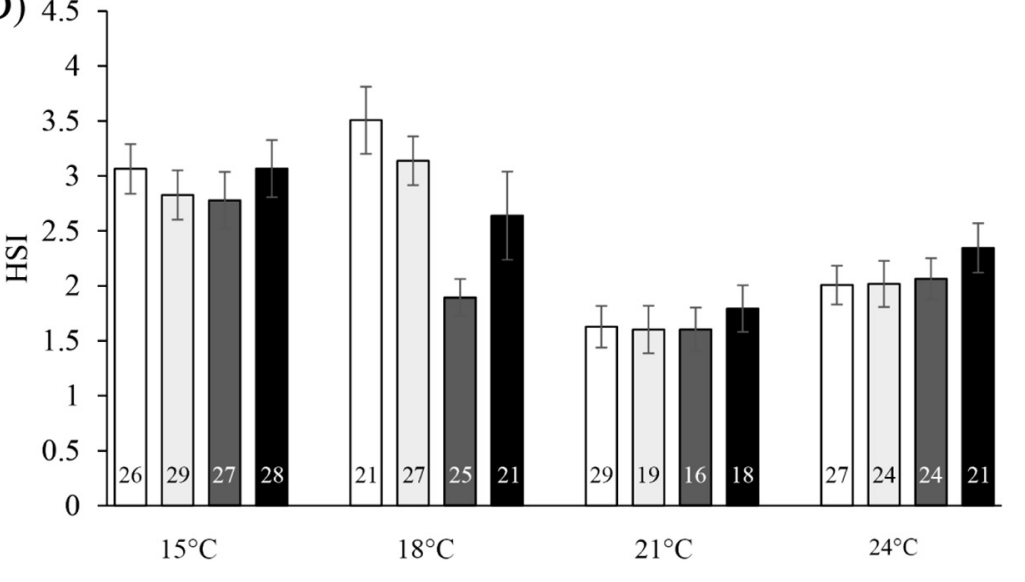

$\square$ Control

口El-L

口E1-M

-El-H 
intense recruitment of glycogen reserve from liver hepatocytes that may not be sustainable during prolonged exposures. This effect may be more apparent in the current study at low temperature as basic metabolic needs increase in a temperature-dependent manner in ectotherms. Thus, fish maintained at the higher temperatures may have depleted their glycogen storage prior to the termination of the exposure experiments.

The anatomical endpoints in this study were substantially influenced by temperature in both males and females. In females, all but one anatomical endpoint (TL) yielded a statistically significant effect of temperature. In addition, the effects of exposure on SL, total weight, liver weight, and HSI were significantly affected by temperature (Fig. 4). Male anatomy was also influenced by temperature to a lesser degree, but not by exposure. Overall, unexposed and E1-L exposed females maintained at lower temperatures were longer, heavier, and had bigger livers than E1-M or E1-H exposed females. Metabolic response to temperature changes is vital to organismal homeostasis under seasonal temperature fluctuations (Bruneaux et al., 2014). Fish maintained at lower temperatures experience a reduced metabolism, which may lead to a decreasing capacity for detoxifying processes, resulting in the internalization of toxins for longer periods of time. Exposure to toxins can result in the accumulation of glycogen or fatty vacuoles in fish livers, hypothesized to occur due to decreased breakdown of macromolecules stemming from the physiological stress of hepatocellular toxicity (Wolf and Wolfe, 2005). In this experiment, male and female liver histology both displayed significantly greater vacuole severity at cooler temperatures $\left(15^{\circ} \mathrm{C}\right.$ and $\left.18{ }^{\circ} \mathrm{C}\right)$ compared to warmer temperatures $\left(21^{\circ} \mathrm{C}\right.$ and $24^{\circ} \mathrm{C}$ ), providing support for the hypothesis that cooler water temperatures decrease metabolism, leading to reduced or impaired detoxifying pathways.

These findings are particularly important to fish populations in northern effluent dominated aquatic ecosystems as fish are more likely to reproduce at cooler temperatures than in more southern latitudes (Shappell et al., 2018). E1-L and E1-M exposure concentrations in the current study represent "worst case scenarios" for environmental E1 concentrations as found in some effluent dominated systems (Schultz et al., 2013) but are lower than reported total estrogenicity in other effluent dominated systems (Alvarez et al., 2013; Kolpin et al., 2002; Schultz et al., 2013). Fish populations in northern latitudes are also frequently drawn to effluent outfalls as temperature refugia during cold winter months when ambient water temperature may approach freezing. Offspring produced during cooler spring water temperatures may, therefore, experience greater exposure consequences than summer broods as has been determined in a separate but related study (Ward et al., 2017). Therefore, the current study highlights differences in the effects of E1 exposure based on regional climatic conditions.

As expected (Suarez et al., 2010; Wild et al., 1971), the onset of nitrification was delayed in the reactors operated at $15^{\circ} \mathrm{C}$ when compared to those operated at room temperature (Fig. 1). While there was also an apparent delay in E1 degradation (Fig. 1), comparable and low $(<0.4 \mu \mathrm{g} / \mathrm{L})$ effluent E1 concentrations were observed in the reactors operated at $15{ }^{\circ} \mathrm{C}$ and room temperature within the first week of reactor operation. This demonstrated that efficient nitrification was not required for E1 removal, only the conditions that could support nitrification (long SRT, low bulk organic carbon concentrations, aeration). Although lower temperatures $\left(<15^{\circ} \mathrm{C}\right)$ could result in a further decline, or even eventual cessation, of E1 degradation, the maintenance of conditions that support nitrification, even in the absence of robust nitrification itself should also support biological E1 degradation. Therefore, given that minnows do not generally reproduce at temperatures $<15$ ${ }^{\circ} \mathrm{C}$, the absence of robust nitrification should still protect those species during sensitive life stages (i.e. reproduction).

\subsection{Conclusion}

Collectively, the results of this experiment demonstrate that fluctuations in temperature over a natural spring-summer range of variation modulate the effects of estrogenic exposure on adult fathead minnow physiology, morphology, and affect E1 degradation. The significant interactions between temperature and E1 exposure observed in this experiment suggest that female fish may be more susceptible to the temperature-modulating effects of estrogenic exposure on morphometric endpoints, but males may be more susceptible to the interactive effects of temperature and E1 exposure on physiological endpoints. The results also indicate that E1 removal under treatment conditions that support nitrification is robust, even at cooler temperatures, though a delay in E1 degradation was observed. Collectively, the data demonstrate that natural seasonal fluctuations in temperature are sufficient to induce significant physiological and anatomical changes in fish upon exposure, and highlight that the responses of males and females can vary markedly under identical exposure regimes. The effects observed in the current study warrant further investigations into the reproductive effects of chemical and non-chemical stressor interactions in laboratory and resident fish populations.

Supplementary data to this article can be found online at https://doi. org/10.1016/j.scitotenv.2017.10.069.

\section{Acknowledgments}

Funding for the present study was provided by the Minnesota Environment and Natural Resources Trust Fund as recommended by the Legislative-Citizen Commission on Minnesota Resources (Grant M.L. 2014, Chp. 226, Sec. 2, Subd. 03d) (PJN; JLW; HLS) and an Animal Behavior Society student research grant (MKC). The authors wish to express their gratitude to the numerous undergraduate and graduate students of the St. Cloud State Aquatic Toxicology Laboratory that assisted in the exposure experiments, particularly David Feifarek, Raingsey Aing, Michelle Matsuura, Jacqueline Blomker, and Jennifer Notch. For their contributions to the nitrification experiments, we appreciate the assistance of Rebecca Alm at the Metropolitan Wastewater Treatment Plant in St. Paul, MN and Sarah Barnett, undergraduate at the University of Minnesota.

\section{References}

Alvarez, D.A., Shappell, N.W., Billey, L.O., Bermudez, D.S., Wilson, V.S., Kolpin, D.W., Perkins, S.D., Evans, N., Foreman, W.T., Gray, J.L., Shipitalo, M.J., Meyer, M.T. 2013. Bioassay of estrogenicity and chemical analyses of estrogens in streams across the United States associated with livestock operations. Water Res. 47, 3347-3363.

Ankley, G.T., Feifarek, D., Blackwell, B., Cavallin, J.E., Jensen, K.M., Kahl, M.D., Poole, S., Randolph, E., Saari, T., Villeneuve, D.L., 2017. Reevaluating the significance of estrone as an environmental estrogen. Environ. Sci. Technol. (In press)

Brian, J.V., Harris, C.A., Runnalls, T.J., Fantinati, A., Pojana, G., Marcomini, A., Booy, P., Lamoree, M., Kortenkamp, A., Sumpter, J.P., 2008. Evidence of temperaturedependent effects on the estrogenic response of fish: implications with regard to climate change. Sci. Total Environ. 397, 72-81.

Bruneaux, M., Nikinmaa, M., Laine, V.N., Lindström, K., Primmer, C.R., Vasemägi, A., 2014. Differences in the metabolic response to temperature acclimation in nine-spined stickleback (Pungitius pungitius) populations from contrasting thermal environments. J. Exp. Zool. A. Ecol. Genet. Physiol. 321 (10), 550-565.

Carson, F.L., 1997. Histotechnology. second ed. ASCP Press, Chicago, IL.

Chen, T.S., Chen, T.C., Yeh, K.J.C., Chao, H.R., Liaw, E.T., Hsieh, C.Y., Chen, K.C., Hsieh, L.T., Yeh, Y.L., 2010. High estrogen concentrations in receiving river discharge from a concentrated livestock feedlot. Sci. Total Environ. 408, 3223-3230.

Dammann, A.A., Shappell, N.W., Bartell, S.E., Schoenfuss, H.L., 2011. Comparing biological effects and potencies of estrone and $17 \beta$-estradiol in mature fathead minnows, Pimephales promelas. Aquat. Toxicol. 105, 559-568.

Del Río Zaragoza, O., Rodríguez, M.H., Bückle Ramirez LF. 2008. Thermal stress effect on tilapia Oreochromis mossambicus (Pisces: Cichlidae) blood parameters. Mar. Freshw. Behav. Physiol. 41 (2), 79-89.

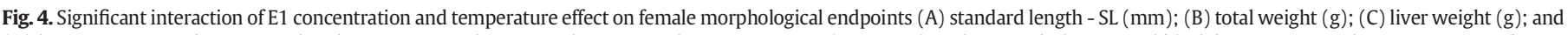

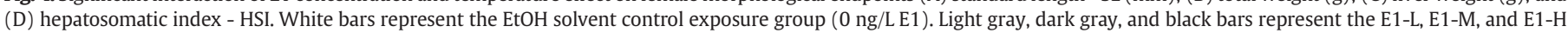
exposure treatments, respectively; bars and error bars depict means \pm SEM. 
Denny, J.S. 1987. Guidelines for the culture of fathead minnows for use in toxicity tests. EPA/600/3-87/001. US Environmental Protection Agency, Environmental Research Laboratory, Duluth.

Ekman, D.R., Teng, Q., Villeneuve, D.L., Kahl, M.D., Jensen, K.M., Durhan, E.J., Ankley, G.T., Collette, T.W., 2008. Investigating compensation and recovery of fathead minnow (Pimephales promelas) exposed to $17 \alpha$-ethynylestradiol with metabolite profiling. Environ. Sci. Technol. 42, 4188-4194.

Freychet, P., Roth, J., Neville Jr., D.M., 1971. Insulin receptors in the liver: specific binding of [125I] insulin to the plasma membrane and its relation to insulin bioactivity. Proc. Nat. Acad. Sci. USA. 68, 1833-1837.

Fulton, T.W., 1904. The Rate of Growth of Fishes. Fisheries Board of Scotland, pp. 141-241 Annual Report 22 part 3.

Gillet, C., Quétin, P., 2006. Effect of temperature changes on the reproductive cycle of roach in Lake Geneva from 1983 to 2001. J. Fish Biol. 69, 518-534.

Gordon, C.J., 2003. Role of environmental stress in the physiological response to chemical toxicants. Environ. Res, 92, 1-7.

Hadley, M.E., Levine, J.E., 2006. Endocrinology. sixth ed. San Francisco, CA

Hemmer, M.J., Bowman, C.J., Hemmer, B.L., Friedman, S.D., Marcovich, D., Kroll, K. Denslow, N., 2002. Vitellogenin mRNA regulation and plasma clearance in male sheepshead minnows, (Cyprinodon variegatus) after cessation of exposure to 178estradiol and p-nonylphenol. Aquat. Toxicol. 58 (1-2), 99-112.

Heugens, E.H.W., Hendriks, A.J., Dekker, T., van Straalen, N.M., Admiraal, W., 2001. A review of the effects of multiple stressors on aquatic organisms and analysis of uncertainty factors for use in risk assessment. Crit. Rev. Toxicol. 31, 247-284.

Hoyt, P.R., Doktyz, M.J., Beattie, K.L., Greenly, M.S., 2003. DNA microarrays detect 4nonylphenol-induced alterations in gene expression during zebrafish early development. Ecotoxicology 12, 469-474.

Hyndman, K.M., Biales, A., Bartell, S.E., Schoenfuss, H.L., 2010. Assessing the effects of exposure timing using 173 -estradiol. Aquat. Toxicol. 96, 264-272.

Jin, Y., Chen, R., Sun, L., Liu, W., Fu, Z., 2009. Photoperiod and temperature influence endocrine disruptive chemical-mediated effects in male adult zerbrafish. Aquat. Toxicol $92,38-43$.

Jobling S, Nolan, M. Tyler, C.R., Brighty, G., Sumpter, J.P., 1998. Widespread sexual disruption in wild fish. Environ. Sci. Technol. 32, 2498-2506.

Johnson, A.C., Williams, R.J., 2004. A model to estimate influent and effluent concentrations of estradiol, estrone, and ethinylestradiol at sewage treatment works. Environ. Sci. Technol. 38, 3649-3658.

Johnston, I.A., Dunn, J., 1987. Temperature acclimation and metabolism in ectotherms with particular reference to teleost fish. Symp. Soc. Exp. Biol. 41, 67-93.

Kidd, K.A., Blanchfield, P.J., Mills, K.H., Palace, V.P., Evans, R.E., Lazorchak, J.M., Flick, R.W., 2007. Collapse of a fish population after exposure to a synthetic estrogen. PNAS 104 8897-8901.

Kolpin, D.W., Furlong, E.T., Meyer, M.T., Thurman, E.M., Zaugg, S.D., Barber, L.B., Buxton, H.T., 2002. Pharmaceuticals, hormones, and other organic wastewater contaminants in U.S. streams, 1999-2000: a national reconnaissance. Environ. Sci. Technol. 36 $1202-1211$.

Körner, O., Kohno, S., Schönenberger, R., Suter, M.J., Knauer, K., Guillette Jr., L.J., Burkhardt, Holm P., 2008. Water temperature and concomitant waterborne ethinylestradiol exposure affects the vitellogenin expression in juvenile brown trout (Salmo trutta). Aquat. Toxicol. 90, 188-196.

Korsgaard, B., Mommsen, T.P., Saunders, R.L., 1986. The effect of temperature on the vitellogenic response in Atlantic salmon post-smolts (Salmo salar). Gen. Comp. Endocrinol. 62, 193-201.

Larsen, D.A., Beckman, B.R., Dickhoff, W.W., 2001. The effect of low temperature and fasting during the winter on metabolic stores and endocrine physiology (insulin, insulin growth-like growth factor-I, and thyroxine) of Coho salmon, Oncorhynchus kisutch. Gen. Comp. Endocrinol. 123, 308-323.

Luquet, P., Watanabe, T., 1986. Interaction "nutrition-reproduction" in fish. Fish Physiol. Biochem. 2, 121-129.

Matthiessen, P. Arnold, D. Johnson, A.C. Pepper, T.J., Pottinger, T.G, Pulman, K.G.T, 2006. Contamination of headwater streams in the United Kingdom by oestrogenic hormones from livestock farms. Sci. Total Environ. 367, 616-630.

de Mes, T., Zeeman, G., Lettinga, G., 2005. Occurrence and fate of estrone, 17ß-estradiol and $17 \alpha$-ethynylestradiol in STPs for domestic wastewater. Rev. Environ. Sci. Biotechnol. 4, 275-311.

Palace, V.P., Evans, R.E., Wautier, K.G., Mills, K.H., Blanchfield, P.J., Park, B.J., Baron, C.L., Kidd, K.A., 2009. Interspecies differences in biochemical, histopathological, and population responses in four wild fish species exposed to ethynylestradiol added to a whole lake. Can. J. Fish. Aquat. Sci. 66, 1920-1935.

Panter, G.H., Thompson, R.S., Sumpter, J.P., 1998. Adverse reproductive effects in male fathead minnows (Pimephales promelas) exposed to environmentally relevant concentrations of the natural oestrogens, oestradiol and oestrone. Aquat. Toxicol. 42, 243-253.

Parks, L.G., Cheek, A.O., Denslow, N.D., Heppell, S.A., McLachlan, J.A., LeBlanc, G.A., Sullivan, C.V., 1999. Fathead minnow (Pimephales promelas) vitellogenin: purification, characterization and quantitative immunoassay for the detection of estrogenic compounds. Comp. Biochem. Physiol. C 123, 113-125.

Parrott, J.L., Blunt, B.R., 2005. Life-cycle exposure of fathead minnows (Pimephales promelas) to an ethinylestradiol concentration below $1 \mathrm{ng} / \mathrm{L}$ reduces egg fertilization success and demasculinizes males. Environ. Toxicol. 20, 131-141.

Peterson, K.N., Tan, D.T., Bezares-Cruz, J.C., Novak, P.J., 2017. Estrone biodegradation in laboratory-scale systems designed for total nitrogen removal from wastewater. Environ. Sci.: Water Res. Technol. https://doi.org/10.1039/C7EW00164A.

Radhakrishnaiah, K., Parvatheswararao, V., 1984. Adaptation to thermal stress in the freshwater eurythermal teleost, Sarotherodon mossambicus. Carbohydrate metabolism-phosphorylase activity. J. Anim. Morphol. Physiol. 31, 195-202.

Raman, D.R., Layton, A.C., Moody, L.B., Easter, J.P., Sayler, G.S., Burns, R.T., Mullen, M.D. 2001. Degradation of estrogens in dairy waste solids: effects of acidification and temperature. Am. Soc. Agric. Eng. 44, 1881-1888.

Routledge, E.J., Sheahan, D., Desbrow, C., Brighty, G.C., Waldock, M., Sumpter, J.P., 1998 dentification of estrogenic chemicals in STW effluent, 2. In vivo responses in trout and roach. Environ. Sci. Technol. 32, 1559-1565.

Schoenfuss, H.L., Bartell, S.E., Bistodeau, T.B., Cediel, R.A., Grove, K.J., Zintek, L., Lee, K.E. Barber, L.B., 2008. Impairment of the reproductive potential of male fathead minnows by environmentally relevant exposures to 4-nonylphenol. Aquat. Toxicol. 86, 91-98.

Schultz, M.M., Minarik, T.A., Martinovic-Weigelt, Curran E.A., Bartell, S.E., Schoenfuss, H.L., 2013. Environmental estrogens in an urban aquatic ecosystem: II. Biological effects. Environ. Int. 61, 138-149.

Shappell, N.W., Hyndman, K.M., Bartell, S.E., Schoenfuss, H.L., 2010. Comparative biological effects and potency of $17-\alpha$ and $17 \beta$-estradiol in fathead minnows. Aquat. Toxicol. $100,1-8$.

Shappell, N.W., Feifarek, D.J., Rearick, D.C., Bartell, S.E., Schoenfuss, H.L., 2018. Do environmental factors affect male fathead minnow (Pimephales promelas) response to estrone? Part 2. Temperature and food availability. Sci. Total Environ. 610-611, 32-43.

Shi, J., Fujisawa, S., Nakai, S., Hosomi, M., 2004. Biodegradation of natural and synthetic estrogen by nitrifying activated sludge and ammonia-oxidizing bacterium Nitrosomonas europaea. Water Res. 38, 2323-2330.

Smith, R.J.F., 1978. Seasonal changes in the histology of the gonads and dorsal skin of the fathead minnow, Pimephales promelas. Can. J. Zool. 56, 2103-2109.

Starner, K., Kuivila, K.M., Jennings, B., Moon, G.E., 1999. Degradation rates of six pesticides in water from the Sacramento River, California. U.S. Geological Survey Toxic Substances Hydrology Program Water Resource Investigation Report 99-4018A, Proceedings of the Technical Meeting, Charleston, SC, pp. 89-99.

Suarez, S., Lema, J.M., Omil, F., 2010. Removal of pharmaceutical and personal care products (PPCPs) under nitrifying and denitrifying conditions. Water Res. 44, 3214-3224

Tan, D.T., Arnold, W.A., Novak, P.J., 2013. Impact of organic carbon on the biodegradation of estrone in mixed culture systems. Environ. Sci. Technol. 47, 12359-12365.

Thorpe, K.L., Benstead, R., Hutchinson, T.H., Cummings, R.I., Tyler, C.R., 2003. Reproductive effects of exposure to oestrone in the fathead minnow. Fish Physiol. Biochem. 28, 451-452.

Vajda, A.M., Barber, L.B., Gray, J.L., Lopez, E.M., Woodling, J.D., Norris, D.O., 2008. Reproductive disruption in fish downstream from an estrogenic wastewater effluent. Environ. Sci. Technol. 42, 3407-3414.

Van den Belt, K., Berckmans, P., Vangenechten, C., Verheyen, R., Witters, H., 2004. Comparative study on the in vitro/in vivo estrogenic potencies of $17 \beta$-estradiol, estrone, $17 \alpha$ ethynylestradiol and nonylphenol. Aquat. Toxicol. 66, 183-195.

Voet, D., Voet, J.G., Pratt, C.W., 2013. Fundamentals of Biochemistry. fourth ed. Hoboken, NJ.

Ward, J.L., Cox, M.K., Schoenfuss, H.L., 2017. Thermal modulation of anthropogenic estrogen exposure on a freshwater fish, Pimephales promelas, at two life stages. Horm Behav. 94, 21-32.

Watanabe, K.H., Jensen, K.M., Orlando, E.F., Ankley, G.H., 2007. What is normal? A charac terization of the values and variability in reproductive endpoints of the fathead minnow, Pimephales promelas. Comp. Biochem. Physiol. C 146, 348-356.

Wild, H.E., Sawyer, C.N., McMahon, T.C., 1971. Factors affecting nitrification kinetics, J. Water Pollut. Control Fed. 43, 1845-1854.

Wolf, J.C., Wolfe, M.J., 2005. A brief overview of nonneoplastic hepatic toxicity in fish. Toxicol. Pathol. 33, 75-85.

Writer, J.H., Ryan, J.N., Keefe, S.H., Barber, L.B., 2012. Fate of 4-nonylphenol and 17ßestradiol in the Redwood River of Minnesota. Environ. Sci. Technol. 46, 860-868. 